\title{
IRON-DEFICIENCY ANAEMIA BETWEEN 3 MONTHS AND 2 YEARS OF AGE AND A COMPARISON OF TREATMENT WITH FERROUS SULPHATE AND FERROUS FUMARATE
}

\author{
BY \\ CHAN GUNN, M. C. ISLIP, P. L. MASTERS, H. ERSKINE-MURRAY, C: A. RIGG and \\ T. STAPLETON \\ From the Paddington Green Children's Hospital, London
}

(RECEIVED FOR PUBLICATION JULY 15, 1959)

A recent paper from this hospital (Morrison, Bass, Davis, Hobson, Madsen and Masters, 1957) reported that about one half of the children under 2 years of age admitted because of acute respiratory infections had haemoglobin concentrations below $11 \mathrm{~g}$. per $100 \mathrm{ml}$. The purposes of the present investigation were to determine the distribution of the haemoglobin levels in children between 3 months and 2 years of age attending the hospital, to compare two forms of iron treatment and to observe whether infection influenced the response to therapy.

For many years ferrous sulphate (iron content about $33 \%$ of exsiccated salt) has been the compound most widely prescribed for the treatment of iron deficiency anaemia. In a small number of patients this causes gastro-intestinal disturbance. The claim has been made that organic compounds of iron are better tolerated. Recently ferrous fumarate, a compound with the empirical formula $\mathrm{FeC}_{4} \mathrm{H}_{2} \mathrm{O}_{4}$, has been advocated (Lancet, 1958). The iron content of ferrous fumarate (about $33 \%$ iron) is higher than that of ferrous gluconate (about $12 \%$ iron) or ferrous succinate (about $25 \%$ iron).

\section{Selection of Patients}

It was intended to include in the survey of haemoglobin levels the values found in all children between 3 months and 2 years of age attending the casualty department with a new complaint or admitted to the medical ward between January 19, 1958 and March 31,1958 . Owing to the large number of children who attended the casualty department, pressure of work made it necessary to include casualty attendances during the morning only for much of the period. One hundred and three children attending the casualty department and 53 admitted to the medical ward were included in the survey. Seventy- three children with haemoglobin levels below $11 \mathrm{~g}$. per $100 \mathrm{ml}$. were observed in the assessment of therapy. Forty-seven of these children were initially seen in the survey and 26 after the survey period ended.

\section{Methods}

Approximately $0.4 \mathrm{ml}$. of capillary blood was collected from each patient into a Pasteur pipette containing dried heparin. The sample was ejected into a small tube, well mixed and immediately used to fill pipettes for estimation of haemoglobin, packed cell volume and erythrocyte sedimentation rate (E.S.R.). The haemoglobin was estimated by the oxyhaemoglobin method described by Dacie (1956). An Ilford 0.5 neutral density screen was read with each series of estimations. Its equivalent haemoglobin value was determined by using blood of known haemoglobin content supplied by Messrs. Keeler Ltd. Each pipette was calibrated. The packed cell volume (P.C.V.) was estimated using capillary tubes spun in a Hawksley microhaematocrit centrifuge at $12,000 \mathrm{~g}$. for five minutes. The E.S.R. was estimated using a tube of $1.5 \mathrm{~mm}$. bore and a column of blood $100 \mathrm{~mm}$. long.

Three mixtures (A, B and C) were prepared; none of the medical staff knew which was issued to a particular child, the records being kept by the pharmacist:

A. Ferrous fumarate in a flavoured suspension containing $75 \mathrm{mg}$. (equivalent to $25 \mathrm{mg}$. elemental iron) per $4 \mathrm{ml}$.

B. Ferrous sulphate in a flavoured vehicle similar to that used for Ferrous Sulphate Mixture for infants (British National Formulary, 1957) modified to contain $120 \mathrm{mg}$. hydrated salt (equivalent to $25 \mathrm{mg}$. elemental iron) per $4 \mathrm{ml}$.

C. A placebo consisting of the flavoured vehicle without ferrous sulphate.

The placebo was given to every third child with a haemoglobin level between 9 and $11 \mathrm{~g}$. per $100 \mathrm{ml}$. presenting in four consecutive weeks of the study in order to have a control group for comparison of side-effects and 
spontaneous haemoglobin changes. It was not felt wise to give the placebo to children with a haemoglobin level below $9 \mathrm{~g}$. per $100 \mathrm{ml}$.

In order to ensure comparability as regards haemoglobin levels and age in the children given ferrous sulphate and ferrous fumarate, the children were allotted to one of four groups:

$\left.\begin{array}{l}3 \text { months-1 year } \\ 1 \text { year-2 years }\end{array}\right\}$ haemoglobin $9-11 \mathrm{~g}$. per $100 \mathrm{ml}$.

3 months-1 year haemoglobin under 9 g. per 1 year-2 years $\int 100 \mathrm{ml}$.

The mixtures were given in rotation to the patients in each group according to the order of arrival of the prescriptions in the pharmacy.

All mixtures were issued with plastic measuring spoons (4 ml. capacity) and the following instructions:

'One teaspoonful after food once a day for 3 days, twice a day for the next 3 days, then three times a day.'

The mother was asked to bring the child back two weeks and four weeks after the start of treatment. On the first return visit she was given another bottle of the same medicine. On each visit the doctor reassessed the child's condition and asked whether any vomiting, diarrhoea or constipation had occurred since the previous visit. Any comments provided by the mother about the child's reaction to the medicine were noted.

\section{Results}

Haemoglobin Levels. Fig. 1 shows the total number of children with haemoglobin levels in each one-gramme range. There is a skew distribution in which $20 \%$ of the children have haemoglobin levels

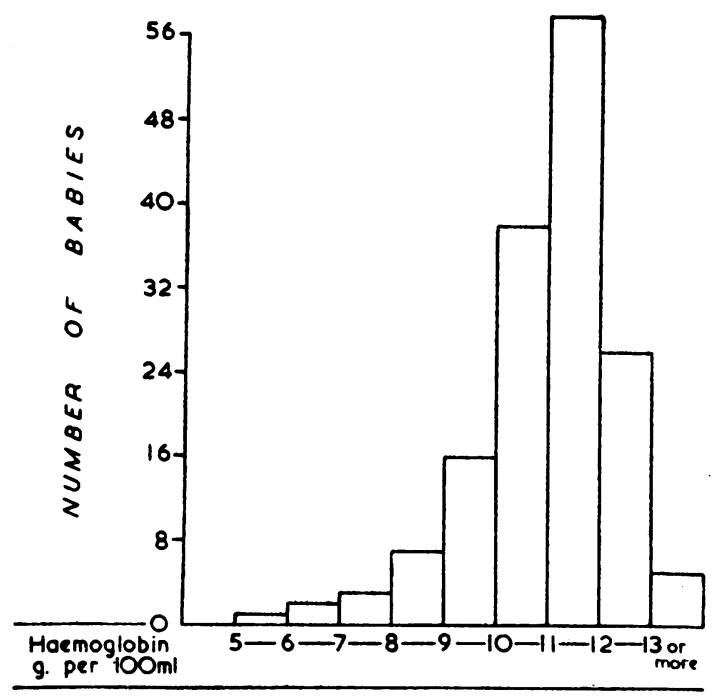

Fig. 1. of 12 g. per $100 \mathrm{ml}$. or more, $37 \%$ have between 11 and $12 \mathrm{~g}$. per $100 \mathrm{ml}$. and $43 \%$ have under $11 \mathrm{~g}$. per $100 \mathrm{ml}$. Of the children requiring admission to the medical ward, $53 \%$ had haemoglobin levels below 11 g. per $100 \mathrm{ml}$, a finding similar to that of Morrison et al. (1957).

Table 1 gives the averages of the mean corpuscular

TABLE 1

CORRELATION OF MEAN CORPUSCULAR HAEMOGLOBIN CONCENTRATIONS WITH HAEMOGLOBIN LEVELS

\begin{tabular}{|c|c|c|c|c|c|}
\hline $\begin{array}{r}\text { Haemoglobin range } \\
(\mathrm{g} . \text { per } 100 \mathrm{ml} .)\end{array}$ & $\begin{array}{c}\text { Under } \\
9\end{array}$ & $9-10$ & $10-11$ & $11-12$ & 12 or more \\
\hline Mean M.C.H.C. (\%) & $27 \cdot 1$ & $30 \cdot 2$ & $31 \cdot 2$ & $32 \cdot 4$ & $32 \cdot 5$ \\
\hline No. of patients ... & 13 & 15 & 38 & 56 & 27 \\
\hline
\end{tabular}

haemoglobin concentrations (M.C.H.C.) of the children in each one-gramme range of haemoglobin level. The progressive reduction in average M.C.H.C. in the lower haemoglobin ranges indicates an irondeficiency factor.

Table 2 gives the average E.S.R. of the children in

TABLE 2

CORRELATION OF ERYTHROCYTE SEDIMENTATION RATES WITH HAEMOGLOBIN LEVELS

\begin{tabular}{|c|c|c|c|c|c|}
\hline $\begin{array}{l}\text { Haemoglobin range } \\
\text { (g. per } 100 \mathrm{ml} \text {.) }\end{array}$ & $\underset{9}{\text { Under }}$ & $9-10$ & $10-11$ & $11-12$ & 12 or more \\
\hline Mean E.S.R. (mm./hr) .. & 30 & 29 & 20 & 16 & 13 \\
\hline No. of patients* & 13 & 16 & 38 & 58 & 31 \\
\hline
\end{tabular}

* The numbers of patients are different from those in Table 1 as the M.C.H.C. was not determined in every patient in whom an E.S.R. was observed and who was included in the survey.

each one-gramme range of haemoglobin level. There is a rise in average E.S.R. from the highest haemoglobin range downwards. Iron deficiency anaemia alone may not cause a rise in the E.S.R. (Terry, 1950); several children in the survey with haemoglobin levels below 9 g. per $100 \mathrm{ml}$. had E.S.R.s of less than $10 \mathrm{~mm}$. in one hour.

Assessment of Iron Therapy. Table 3 shows the acceptability of the three medicines (A, B and C). Only about one third as many children received the placebo as received either of the iron mixtures. A liking for the medicine was remarked by the mothers in a majority of children receiving the placebo and only in a few of the children receiving the iron mixtures. A distaste for the medicine was confined to the children receiving the iron mixtures and was slightly more frequent in children receiving 
TABLE 3

COMPARISON OF ACCEPTABILITY OF MEDICINES

\begin{tabular}{|c|c|c|c|}
\hline & $\begin{array}{l}\text { Ferrous } \\
\text { Fumarate }\end{array}$ & $\begin{array}{l}\text { Ferrous } \\
\text { Sulphate }\end{array}$ & Placebo \\
\hline 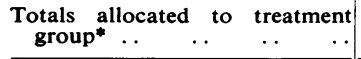 & 31 & 31 & 11 \\
\hline $\begin{array}{l}\text { Number returning once } . \\
\text { Number returning twice }\end{array}$ & $\begin{array}{l}24 \\
22\end{array}$ & $\begin{array}{l}27 \\
22\end{array}$ & $\begin{array}{l}9 \\
7\end{array}$ \\
\hline $\begin{array}{l}\text { Number liking medicine } \\
\text { Number disliking medicine }\end{array}$ & $\begin{array}{l}3 \\
4\end{array}$ & $\begin{array}{r}4 \\
10\end{array}$ & $\begin{array}{l}5 \\
0\end{array}$ \\
\hline $\begin{array}{l}\text { Vomiting .. } \\
\text { Diarrhoea } \\
\text { Constipation }\end{array}$ & $\begin{array}{l}1 \\
1 \\
3\end{array}$ & $\begin{array}{l}0 \\
0 \\
4\end{array}$ & $\begin{array}{l}0 \\
1 \\
2\end{array}$ \\
\hline
\end{tabular}

* Includes nine babies who did not complete their course of medicine.

ferrous sulphate. Vomiting, diarrhoea or constipation were noted in only a small proportion of children. A comparison of their incidence in the iron-treated groups and placebo group reveals no evidence that these symptoms were related to the administration of either iron mixture. There were no other symptoms attributable to the iron mixtures.

Table 4 compares the haemoglobin responses to

TABLE 4

COMPARISON OF HAEMOGLOBIN RESPONSE TO EACH MEDICINE IN PATIENTS WITH INITIAL HAEMOGLOBIN LEVELS BETWEEN 9 AND 11 g. PER $100 \mathrm{ml}$.

\begin{tabular}{|c|c|c|c|c|}
\hline & & \multicolumn{3}{|c|}{ Mean Haemoglobin (g. per $100 \mathrm{ml}$.) } \\
\hline & & $\begin{array}{c}\text { Ferrous } \\
\text { Fumarate }\end{array}$ & $\begin{array}{l}\text { Ferrous } \\
\text { Sulphate }\end{array}$ & Placebo \\
\hline $\begin{array}{l}\text { Initially } \\
\text { After } 2 \text { weeks } \\
\text { After } 4 \text { weeks }\end{array}$ & $\begin{array}{l}\ldots \\
\cdots\end{array}$ & $\begin{array}{l}10 \cdot 1^{*} \\
10 \cdot 8 \\
11 \cdot 5\end{array}$ & $\begin{array}{l}10 \cdot 0^{*} \\
11 \cdot 0 \\
11 \cdot 3\end{array}$ & $\begin{array}{l}10 \cdot 3^{*} \\
10 \cdot 6 \\
10 \cdot 7\end{array}$ \\
\hline Rise after 4 weeks & . & $1 \cdot 4$ & $1 \cdot 3$ & $0 \cdot 4$ \\
\hline Number of patients & $\ldots$ & 14 & 15 & 7 \\
\hline
\end{tabular}

* There is no significant difference between the initial haemoglobin levels in the groups receiving iron therapy and the placebo group $(p>0 \cdot 10)$. The mean change in haemoglobin level of those children receiving either type of iron therapy is significantly greater than of those receiving the placebo $(p<0 \cdot 01)$. the three medicines in the slightly anaemic children. The mean responses to the two iron mixtures were almost equal and considerably more than the change occurring in the group receiving the placebo.

Table 5 compares the haemoglobin and M.C.H.C.

TABLE 5

COMPARISON OF HAEMOGLOBIN AND M. C. C. RESPONSE TO EACH MEDICINE IN PATIENTS WITH INITIAL HAEMOGLOBIN LEVELS BELOW 9 g. PER $100 \mathrm{ml}$.

\begin{tabular}{|c|c|c|c|c|c|}
\hline & & \multicolumn{2}{|c|}{$\begin{array}{l}\text { Mean Haemoglobin } \\
\text { (g. per } 100 \mathrm{ml} \text {.) }\end{array}$} & \multicolumn{2}{|c|}{ Mean $\underset{(\%)}{\text { M.C.H.C. }}$} \\
\hline & & $\begin{array}{l}\text { Ferrous } \\
\text { Fumarate }\end{array}$ & $\begin{array}{l}\text { Ferrous } \\
\text { Sulphate }\end{array}$ & $\begin{array}{c}\text { Ferrous } \\
\text { Fumarate }\end{array}$ & $\begin{array}{l}\text { Ferrous } \\
\text { Sulphate }\end{array}$ \\
\hline $\begin{array}{l}\text { Initially } \\
\text { After } 2 \text { weeks } \\
\text { After } 4 \text { weeks }\end{array}$ & $\begin{array}{l}. \\
\therefore \\
.\end{array}$ & $\begin{array}{r}6 \cdot 8 \\
8 \cdot 7 \\
10 \cdot 4\end{array}$ & $\begin{array}{r}8 \cdot 0 \\
9 \cdot 6 \\
10 \cdot 4\end{array}$ & $\begin{array}{l}25 \cdot 8 \\
26 \cdot 4 \\
27 \cdot 5\end{array}$ & $\begin{array}{l}27 \cdot 5 \\
27 \cdot 5 \\
29 \cdot 4\end{array}$ \\
\hline Rise & .. & $3 \cdot 6$ & $2 \cdot 4$ & $1 \cdot 7$ & 1.9 \\
\hline No. of patients & & 8 & 7 & 7 & 7 \\
\hline
\end{tabular}

responses to the two iron mixtures in the children with initial haemoglobin levels below $9 \mathrm{~g}$. per $100 \mathrm{ml}$. There was a good response to both iron mixtures. As would be expected, the response to iron therapy is greater when the haemoglobin level is lower. The response is noticeable even when the initial haemoglobin level is between 10 and $11 \mathrm{~g}$. per $100 \mathrm{ml}$., the average rise in these patients being just over 1 g. per $100 \mathrm{ml}$.

Table 6 is an attempt to assess whether the infections found in the slightly anaemic children and the course they took influenced the response to iron therapy. It can be seen that there was no substantial difference between the haemoglobin responses in the groups selected on the basis of E.S.R. patterns.

\section{Summary}

Anaemia is still a common finding in young children attending this hospital. The anaemia

TABLE 6

CORRELATION OF E.S.R. LEVELS WITH RESPONSE TO IRON THERAPY IN BABIES WITH HAEMOGLOBIN LEVELS INITIALLY 9-11 g. PER $100 \mathrm{ml}$.

\begin{tabular}{|c|c|c|c|c|c|c|c|c|c|c|c|}
\hline \multirow{3}{*}{$\begin{array}{c}\text { No. } \\
\text { of } \\
\text { Babies }\end{array}$} & \multicolumn{7}{|c|}{ E.S.R. Group* } & \multirow{2}{*}{\multicolumn{4}{|c|}{$\begin{array}{c}\text { Response to Iron Therapy } \\
\text { Mean Haemoglobin (g. per } 100 \mathrm{ml} \text {.) }\end{array}$}} \\
\hline & \multirow{2}{*}{\multicolumn{3}{|c|}{ Description }} & \multicolumn{4}{|c|}{ Mean E.S.R. Values (mm.) } & & & & \\
\hline & & & & & Initial & 2 weeks & 4 weeks & Initial & 2 weeks & 4 weeks & Mean Rise \\
\hline 9 & All E.S.R.s under $15 \mathrm{~mm}$. $/ \mathrm{hr} . \quad \ldots$ & .. & . & & 3 & 7 & 6 & $10 \cdot 2$ & $10 \cdot 8$ & $11 \cdot 8$ & 1.6 \\
\hline 11 & Final E.S.R. at least $15 \mathrm{~mm} . / \mathrm{hr} .1$ & & itial E.S.R. & & 41 & 18 & 13 & $10 \cdot 0$ & $11 \cdot 0$ & $11 \cdot 2$ & $1 \cdot 2$ \\
\hline 8 & Remainder & .. & . & & 17 & 13 & 19 & $9 \cdot 7$ & $10 \cdot 4$ & $10 \cdot 9$ & $1 \cdot 2$ \\
\hline
\end{tabular}

- If a high E.S.R. is taken to indicate infection and a fall improvement of infection, the first group would be babies with slight infection, the second with an improving infection and the third with continuing infection. 
usually responds to oral iron therapy, whether given as a ferrous sulphate or a ferrous fumarate mixture, both being generally palatable. The presence of a persistently raised E.S.R. (an indication of infection) is not associated with a substantial reduction in the response to iron therapy.

Thanks are due to Mr. Arnold R. Horwell for the loan of the Hawksley Microhaematocrit centrifuge, and to Glaxo Laboratories for supplying the iron mixtures.

\section{REFERENCES}

Dacie, J. V. (1956). Practical Haematology, 2nd ed. Churchill,

London.
Lancet (1958). Iron deficiency in man, 1, 1162.

Morrison, B., Bass, D., Davis, J. A., Hobson, D., Madsen, T. I. and Masters, P. L. (1957). Acute lower-respiratory infections in childhood. Lancet, 2, 1077.

Terry, R. (1950). Erythrocyte sedimentation in anaemia, Brit. med. J., 2, 1296. 